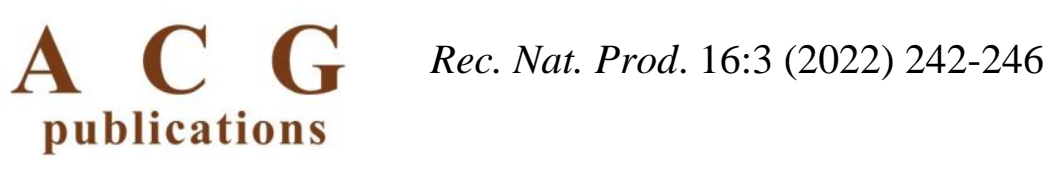

records of natural products

\title{
Scopariaine A: a New Alkaloid from Scoparia dulcis with Protective effect on Cardiomyocytes Injury in Vitro
}

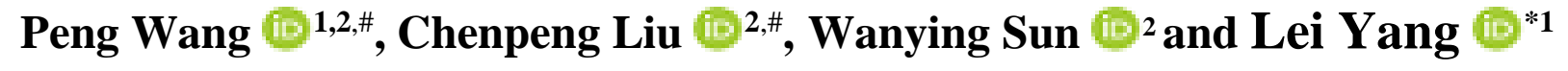 \\ ${ }^{1}$ Hangzhou Normal University, Zhejiang, Hangzhou, 311121, P. R. China \\ ${ }^{2}$ Key Laboratory of Emergency and Trauma, Ministry of Education, \\ College of Emergency and Trauma, Hainan Medical University, \\ Haikou, 571199, P. R. China \\ (Received May 14, 2021; Revised June 30, 2021; Accepted July 02, 2021)
}

\begin{abstract}
A new alkaloid, termed scopariaine A (1), was obtained from the whole plant of Scoparia dulcis L. The new structure was established by applying various spectroscopic methods including $1 \mathrm{D}\left({ }^{1} \mathrm{H}-,{ }^{13} \mathrm{C}-\mathrm{NMR}\right), 2 \mathrm{D}-\mathrm{NMR}$ (HMBC, HSQC) and high resolution electrospray ionization mass spectrometry (HR-ESI-MS). Scopariaine A (1) was tested for its protective effect on attenuating palmitate-induced viability at 5,10 and $25 \mu \mathrm{M}$. The results showed that the cell viability was significantly increased in palmitic acid combined with scopariaine A treated H9C2 cells.
\end{abstract}

Keywords: Scoparia dulcis L.; scopariaine A; alkaloid; H9C2 cells. @ 2021 ACG Publications. All rights reserved.

\section{Plant Source}

The alkaloids in Scoparia dulcis L. have attracted much attention from chemists and pharmacologists worldwide. These alkaloids, mainly coixol and its derivatives, have various biological activities. In the course of finding new alkaloids from Scoparia dulcis L, a new alkaloid scopariaine A (1) was obtained. Herein, we report the isolation, structural elucidation, and its protective effect on the model of cardiomyocytes injury induced by high concentration of palmitic acid in H9C2 cells (Figure 1).

The whole plants of S. dulcis were collected from Wuzhi Mountain of Hainan Province in 2018. The plant was authenticated by Prof. Yuguang Fan, and a voucher specimen (No.SD201807) with a FMHU code (FHMU6255) was deposited at the herbarium of Hainan Medical University.

\section{Previous Studies}

The stems and leaves of $S$. dulcis are sweet when chewing. Therefore, it was called sweet broomwort herb. Interestingly, S. dulcis is a medicinal plant to treat diabetes and gastric ulcer, etc [1,2]. Many pharmacological studies revealed that this plant had the ability in anti-diabetic, anti-inflammatory,

\footnotetext{
\# Authors contributed equally to this paper.

* Corresponding author: E-Mail: yanglei62@hznu.edu.cn; Phone: +86-13989809628

The article was published by ACG Publications

http://www.acgpubs.org/journal/records-of-natural-products May-June 2022 EISSN:1307-6167

DOI: http://doi.org/10.25135/rnp.268.2105.2073 Available online: July 23, 2021
} 
Wang et al., Rec. Nat. Prod. (2022) 16:3 242-246

and the anti-gastric ulcer [3,4]. In chemical investigations, alkaloids such as coixol, 6metoxibenzoxazolinone, diterpenes, and others were obtained from S. dulcis [5-7].

\section{Present Study}

The whole plants of $S$. dulcis $(10.0 \mathrm{~kg})$ were dried in shade and cut into small pieces. Then the plants were extracted under reflux by ethanol for three times. The ethanol extract was concentrated under reduced pressure to give a residue $(1.20 \mathrm{~kg})$. The residue was dissolved in water and extracted by petroleum. The residue was then partitioned by dichloromethane for three times. The dichloromethane extract was isolated by silica gel column chromatography using a gradient ratio of petroleumdichloromethane-acetone as the eluent to give six fractions (Fra.1-Fra.6). Fra.5 was subjected to a Sephadex LH-20 using methanol as the eluent and then purified by HPLC using a mixture of methanolwater (40:60) to afford $\mathbf{1}(5.0 \mathrm{mg})$.

Scopariaine A (1): colorless crystal (MeOH), m.p. $238-240{ }^{\circ} \mathrm{C}$, UV (MeOH) $\lambda_{\max }(\log \varepsilon) 248$ (3.86), 286 (2.24) nm. ${ }^{1} \mathrm{H}$ NMR $\left(600 \mathrm{MHz}, \mathrm{CDCl}_{3}\right) \delta(\mathrm{ppm})=3.44(2 \mathrm{H}, \mathrm{t}, J=7.2 \mathrm{~Hz}, \mathrm{H}-9), 3.80\left(3 \mathrm{H}, \mathrm{s}, 6-\mathrm{OCH}_{3}\right)$, $4.23(2 \mathrm{H}, \mathrm{t}, J=7.2 \mathrm{~Hz}, \mathrm{H}-8), 6.76(1 \mathrm{H}, \mathrm{dd}, J=8.4,2.4 \mathrm{~Hz}, \mathrm{H}-5), 6.82(1 \mathrm{H}, \mathrm{d}, J=2.4 \mathrm{~Hz}, \mathrm{H}-7), 6.86$ $(2 \mathrm{H}, \mathrm{d}, J=8.4 \mathrm{~Hz}, \mathrm{H}-12,16), 7.01(1 \mathrm{H}, \mathrm{d}, J=8.4 \mathrm{~Hz}, \mathrm{H}-13,15), 7.87(2 \mathrm{H}, \mathrm{d}, J=8.4 \mathrm{~Hz}, \mathrm{H}-12,16) .{ }^{13} \mathrm{C}$ NMR $\left(150 \mathrm{MHz}, \mathrm{CDCl}_{3}\right) \delta(\mathrm{ppm})=35.9(\mathrm{C}-8), 37.7(\mathrm{C}-9), 56.0\left(6-\mathrm{OCH}_{3}\right), 97.6(\mathrm{C}-7), 109.2(\mathrm{C}-4)$, 109.4 (C-5), 115.5 (C-13, 15), 124.7 (C-3a), 129.7 (C-11), 130.7 (C-12, 16), 130.7 (C-11), 143.3 (C-7a), 155.0 (C-2), 156.1 (C-6), 160.3 (C-14), 195.5 (C-10). HR-ESI-MS: $m / z 336.0846\left(\left[\mathrm{M}+\mathrm{Na}^{+}\right.\right.$, calcd. $\mathrm{C}_{17} \mathrm{H}_{15} \mathrm{NO}_{5}$ for 336.0848$)$.

Bioactivity Test-Cell Viability Assay: Cell viability was assessed by the MTT assay as previous report [8]. Cells were incubated with 5, 10 and $25 \mu \mathrm{M}$ of scopariaine A and palmitic acid. Then the cell viability was measured.

The whole plant of $S$. dulcis was dried, cut into pieces, and extracted with ethanol. The extract was concentrated under reduced pressure to give a residue. The residue was subjected to conventional purification procedures and resulting in the isolation of scopariaine A (Figure 1).

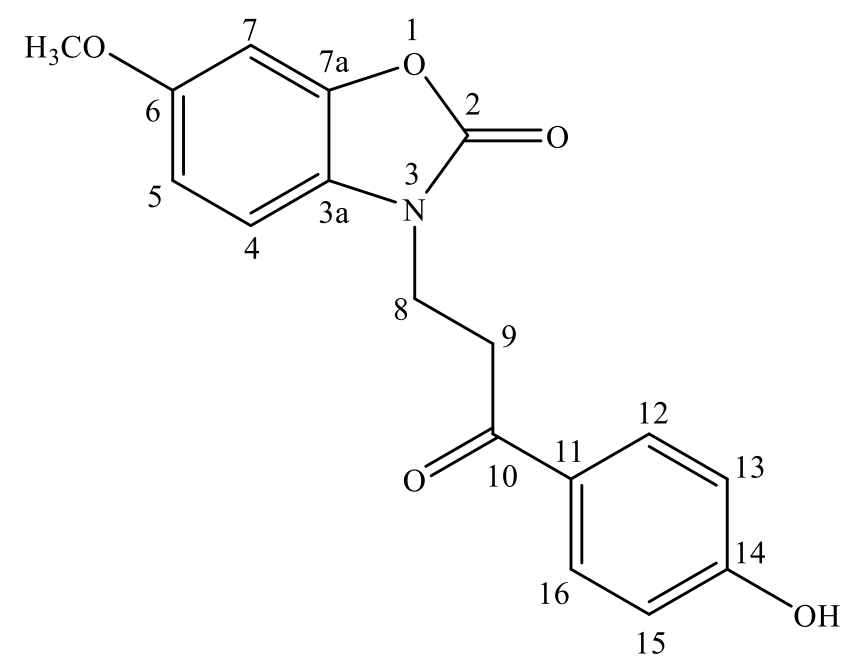

Figure 1. Structure of scopariaine A (1) isolated from Scoparia dulcis

Compound 1, scopariaine A, was obtained as a colorless crystal. Its molecular formula $\mathrm{C}_{17} \mathrm{H}_{15} \mathrm{NO}_{5}$ was determined by analyzing the HR-ESI-MS at $\mathrm{m} / \mathrm{z} 336.0846\left([\mathrm{M}+\mathrm{Na}]^{+}(\right.$calcd 336.0848$)$. The ${ }^{1} \mathrm{H}$ 


\section{Scopariaine A: a new Aalkaloid from Scoparia dulcis}

NMR spectrum exhibited signals for one methoxyl group $\left[\delta_{\mathrm{H}} 3.80\left(3 \mathrm{H}, \mathrm{s}, 6-\mathrm{OCH}_{3}\right)\right.$, a set of benzoyl protons $\left[\delta_{\mathrm{H}} 6.76(1 \mathrm{H}, \mathrm{dd}, J=8.4,2.4 \mathrm{~Hz}, \mathrm{H}-5), 6.82(1 \mathrm{H}, \mathrm{d}, J=2.4 \mathrm{~Hz}, \mathrm{H}-7), 6.86(2 \mathrm{H}, \mathrm{d}, J=8.4 \mathrm{~Hz}\right.$, $\mathrm{H}-5), 7.01(1 \mathrm{H}, \mathrm{d}, J=8.4 \mathrm{~Hz}, \mathrm{H}-13,15), 7.87(2 \mathrm{H}, \mathrm{d}, J=8.4 \mathrm{~Hz}, \mathrm{H}-12,16)]$, two methylene groups $[3.44(2 \mathrm{H}, \mathrm{t}, J=7.2 \mathrm{~Hz}, \mathrm{H}-9), 4.23(2 \mathrm{H}, \mathrm{t}, J=7.2 \mathrm{~Hz}, \mathrm{H}-8)]$. The ${ }^{13} \mathrm{C}$ NMR spectrum, associated with HSQC experiment, resolved 17 carbon signals of two benzoyl groups [97.6 (C-7), 109.2 (C-4), 109.4 (C-6), 115.5 (C-13, 15), 124.7 (C-3a), 129.7 (C-11), 130.7 (C-12, 16), 130.7 (C-11), 143.3 (C-7a), 155.0 $(\mathrm{C}-2), 156.1(\mathrm{C}-6), 160.3(\mathrm{C}-14)]$, one methoxyl [ $\left.\delta_{\mathrm{C}} 56.0\right]$, two methylenes [ $\left.\delta_{\mathrm{C}} 35.9(\mathrm{C}-8), 37.7(\mathrm{C}-9)\right]$, two carbonyl groups $\left[\delta_{\mathrm{C}} 155.0(\mathrm{C}-2), 195.5(\mathrm{C}-10)\right]$.

The HMBC spectrum of 1 exhibited correlation from $\delta_{\mathrm{H}} 6.82(\mathrm{H}-7)$ to carbons at $\delta_{\mathrm{C}} 143.3(\mathrm{C}-7 \mathrm{a})$, $\delta_{\mathrm{C}} 124.7(\mathrm{C}-3 \mathrm{a})$, and correlations from $\delta_{\mathrm{H}} 6.76(\mathrm{H}-5)$ to carbons at $\delta_{\mathrm{C}} 156.1(\mathrm{C}-6)$, and correlations from $\delta_{\mathrm{H}} 6.86(\mathrm{H}-4)$ to carbons at $\delta_{\mathrm{C}} 124.7(\mathrm{C}-3 \mathrm{a}), \delta_{\mathrm{C}} 109.4(\mathrm{C}-5), 151.6(\mathrm{C}-6)$ allowed the elucidation of the coixol part [8]. HMBC correlations from the methylene protons $\delta_{\mathrm{H}} 4.23(\mathrm{H}-8)$ to carbons at $\delta_{\mathrm{C}} 37.7(\mathrm{C}-$ 9), $195.5(\mathrm{C}-10), 155.0(\mathrm{C}-2), 124.7(\mathrm{C}-3 \mathrm{a})$, and correlations from proton at $\delta_{\mathrm{H}} 7.01(\mathrm{H}-12,16)$ to $\delta_{\mathrm{C}}$ 195.5 (C-10), 130.7 (C-11), 160.3 (C-14) allowed the determination of connection between N3-C8 and the establishment of the structure of $\mathbf{1}$. Thus, compound $\mathbf{1}$ was elucidated with a given name scopariaine A as depicted in Figure 1.

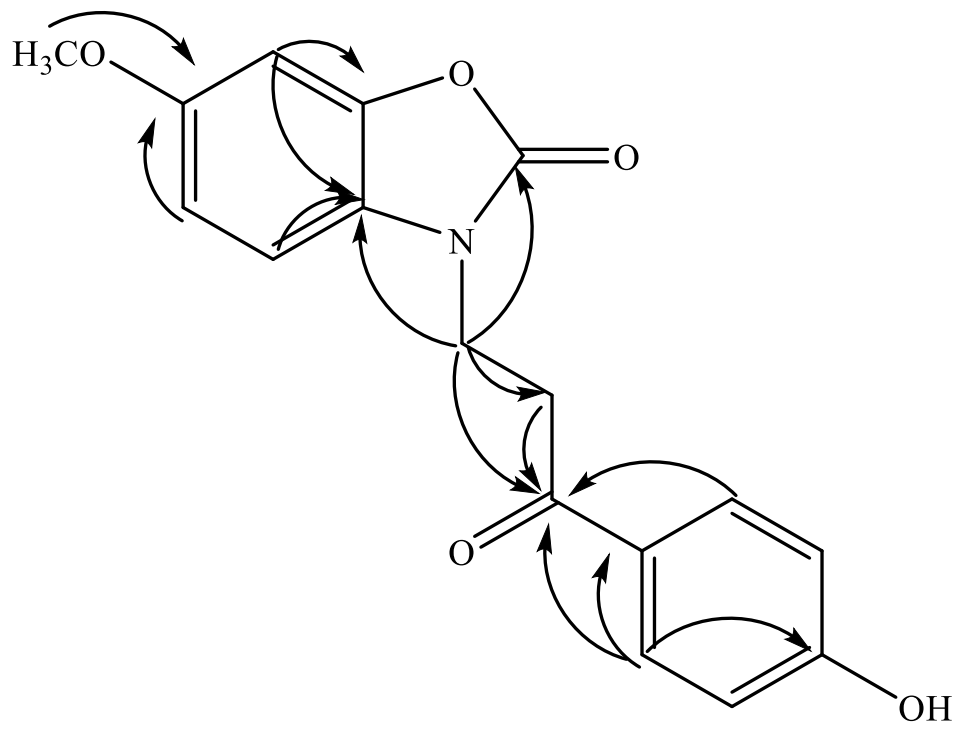

Figure 2. Important HMBC (arrow) correlations for scopariaine A (1)

Scopariaine A was tested for its protective effect on the model of cardiomyocytes injury induced by high concentration of palmitic acid in $\mathrm{H} 9 \mathrm{C} 2$ cells. The result showed that the new compound relieved cardiomyocyte injury induced by palmitic acid and attenuated the viability by palmitateinduced decrease in $\mathrm{H} 9 \mathrm{C} 2$ cells as depicted in Figure 3. 
Wang et al., Rec. Nat. Prod. (2022) 16:3 242-246

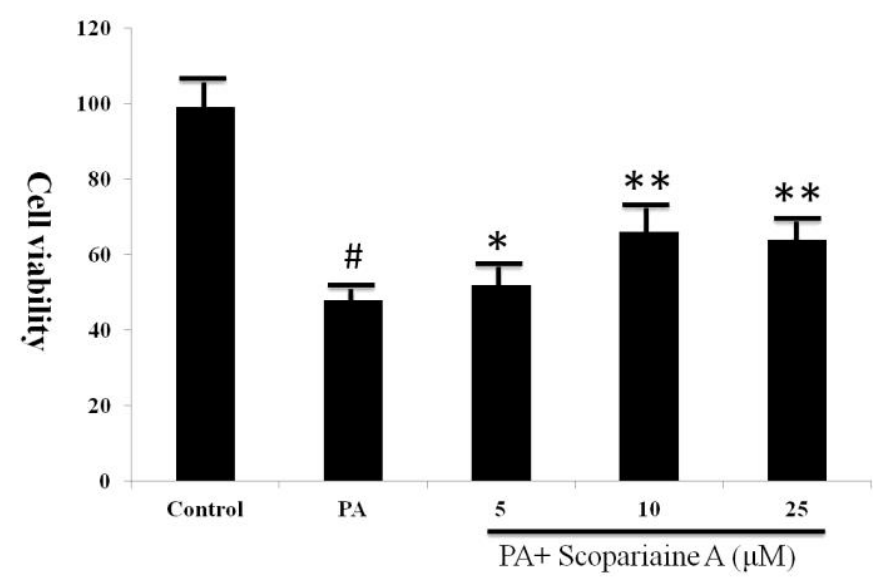

Figure 3. Cell viability treated by scopariaine $A(\mathbf{1})$ in $\mathrm{H} 9 \mathrm{C} 2$ cells. \# $p<0.01$ compared with control, $* \mathrm{p}<0.05$ compared with PA, $* * \mathrm{p}<0.01$ compared with PA

\section{Acknowledgments}

This work was supported by the Key Laboratory of Emergency and Trauma (Hainan Medical University), Ministry of Education (KLET-202003).

\section{Supporting Information}

Supporting Information accompanies this paper on http://www.acgpubs.org/journal/records-ofnatural-products

\section{ORCID}

Peng Wang: 0000-0001-5449-9781

Chenpeng Liu: 0000-0002-6682-4470

Wanying Sun: 0000-0002-1157-5489

Lei Yang: $\underline{0000-0001-7618-9936}$

\section{References}

[1] M. Latha, K. M. Ramkumar, L. Pari, P. N. Damodaran, V. Rajeshkanna and T. Suresh (2006). Phytochemical and antimicrobial study of an antidiabetic plant: Scoparia dulcis L., J. Med. Food 9, 391394.

[2] J. C. Tsai, W. H. Peng, T. H. Chiu, S. H. Huang, T. H. Huang, S. H. Lai, Z. R. Lai and C. Y. Lee (2010). Hepatoprotective effect of Scoparia dulcis on carbon tetrachloride induced acute liver injury in mice, Am. J. Chin. Medicin. 38, 761-775.

[3] M. Latha, L. Pari, K. M. Ramkumar, P. Rajaguru, T. Suresh, T. Dhanabal, S. Sitasawad and R. Bhonde (2009). Antidiabetic effects of scoparic acid D isolated from Scoparia dulcis inrats with streptozotocininduced diabetes, Nat. Prod. Res. 23, 1528-1540.

[4] W. H. Wu, Y. T. Chen, R. W. Lu, S. T. Chen and C. C. Chang (2012). Benzoxazinoids from Scoparia dulcis (sweet broomweed) with antiproliferative activity against the DU-145 human prostate cancer cell line, Phytochemistry 83,110-115.

[5] S. Mandal, C. Kumar, A. Majumder, R. Majumder and B. Maity (2000). Antibacterial activity of Litsea glutinosa bark, Fitoterapia 71, 439-441.

[6] M. Ahsan, S. K. Islam, A. I. Gray and W. H. Stimson (2003). Cytotoxic diterpenes from Scoparia dulcis, 


\section{Scopariaine A: a new Aalkaloid from Scoparia dulcis}

J. Nat. Prod. 66, 958-961.

[7] Y. Li, X. Chen, M. Satake, Y. Oshima and Y. Ohizumi (2004). Acetylated flavonoid glycosides potentiating NGF action from Scoparia dulcis, J. Nat. Prod. 67, 725-727.

[8] Y. P. Chen, W. W. Kuo, R. Baskaran, C. H. Day, R. J. Chen, S. Y. Wen, T. J. Ho, V. V. Padma, C. H. Kuo, and C. Y. Huang (2018). Acute hypoxic preconditioning prevents palmitic acid-induced cardiomyocyte apoptosis via switching metabolic GLUT4-glucose pathway back to CD36-fatty acid dependent, J. Cell. Biochem. 119, 3363-3372.

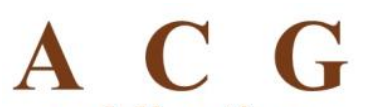

publications

(C) 2021 ACG Publications 